\title{
State intervention in the context of creative industries
}

Anna Drab-Kurowska, Ph.D. Szczecin University Faculty of Management and Economics of Services

\section{Introduction}

The currently growing interest in the role of culture and creative sectors in the context of the economy is observed not only among scientists. Both in Poland and abroad, effort has been made to support the creative sector. It should be pointed that the effort can be seen in including it in economic development strategies by political decision makers at various levels, in terms of goals and measures focusing on creative industries. Consequently, at local and regional levels, strategies and programs are developed focusing on the development of creative industries in a given area, which further highlights the role attributed to the sector (Tomaszewska 2013, p. 18).

The article aims at presenting the meaning of state interventionism on the development of the creative sector. The article attempts to indicate reasons why the state should continue such effort. Moreover, the article suggests possible areas and measures of influence. The goal is implemented based on the domestic and foreign professional literature and reports by international institutions focusing on the functioning of creative sectors, as well as observations of the Polish creative sector. 
The support for creative sectors aims at building a society, success of which is not the result of financial advancement but for which wealth has humanistic values, environmental quality and social solidarity.

It should be highlighted that the fundamental role of governments is to ensure (UNCTAD 2008, p. 174):

- efficient resource allocation in the economy,

- full employment, price stability and external balance, and

- equitable distribution of income and wealth.

While describing creative sectors, we may conclude that state interventions in the context of creative sectors fit into those functions. Further examination of state interventionism into the creative sector necessitate to refer to the idea of interventionism.

\section{Interventionism in the theory of economy}

The doctrine of state interventionism is based on the assumption that the state needs to counteract negative phenomena resulting from the operation of the free market. Moreover, the state might be required to take over certain functions the market cannot fulfil efficiently, i.e. the creative sector.

It should be emphasized that the state interventionism today aimed at stabilizing the economic situation within the policy of counteracting periodical imbalances in the economy is still used to a certain extent in all countries of the world. However, among capitalist countries, highly developed ones encounter broader interventionism. In those countries, intensive development effort is made in the context of creative industries.

If we continue analyzing the interventionism, it should be emphasized that in developed European economies the basic scope of state intervention observes rules developed by $W$. Eucken, the main representative of ordoliberalizm. Those rules include the following (Buko 2009, pp. 53-55):

- counteracting monopolies, and if it is unavoidable, ensuring conditions that are as close to competitive environment as possible,

- financial policy measures revising distribution of the national product,

- supporting businesses in taking into account negative impacts of measures applied.

The social market economy, which is the result of ordoliberalizm, based on business freedom, private ownership and solidarity, dialogue and collaboration of social partners, is at the foundation of the Polish economic system. 
In general, EU member states believe that state interventionism should be temporary and used only when necessary due to a socio-economic situation. The same is expressed by political decision makers in the context of the creative industry. Moreover, the intervention by the state should be possibly limited while giving preference to market regulation. The degree of regulation expresses the trend towards social integration and responds to the complexity and probabilizm of the social system, i.e. the need to reduce diversity and increase the degree of organization. The role of public authorities in their influence on the economy boils down to selecting those areas where development needs to be stimulated or limited, and applying relevant measures that enable influencing those selected areas of the economy, including the creative sector. It should be added that the approach is expressed by establishing specific, sector related regulatory bodies (Czaplewski 2015, pp. 165-166). It should also be pointed out the concept of local interventionism, which is important for the development of the creative industry. While the primary goal of government interventionism is creation macroeconomic conditions for the desired development of the entire economy national self-government intervention is aimed at weakening the failures of local markets and their ties with supra-local markets, and to correct negative structural adjustments to local ones markets (Sztando, 2010, Patrzalek, 1996).

\section{Intervention and the creative sector}

At the early stage of its development, the creative sector needs to be supported by the state. Due to their major impact on the development of the economy and the society, cultural organizations and creative companies, which generate creativity, should attract more interest and support from state institutions. It should be emphasized that the local government may influence creative sectors by its authority in planning spatial development, giving concessions and licenses, adopting regulations, controlling standards of trade and the quality of healthcare system, security during mass events, and exercising its strategic and financial role in education. The support of state institutions should be based on their competences and does not require any additional financial contributions (Kotylak 2009, p. 121).

While using relevant economic policy tools, the state at national, regional and local levels may support creative sectors by determining priorities for the socioeconomic development. It should be emphasized that creative sectors provide a wide range of benefits, including creation of interesting jobs and primarily innovation and enhancing productivity. The latter leads to improved quality of 
life for citizens. Additionally, creative sectors initiate new ideas, and promote exchange of opinions and views.

The functioning of the creative sector depends much on the support of the government and availability of public funding. The state plays a fundamental role as the initiator and coordinator of various activities influencing conditions for the creative sector (Oakley et al.)

In the context of the state policy applicable to creative sectors, the following arguments are used to justify the intervention of the public sector (DCMS 2009, pp. 6-9):

1. Cultural and creative sectors are treated as areas generating benefits for the society that are not based on competition and do not exclude the use of public goods. For this reason, public intervention on the market is not considered negative and distorting to competition.

2. Intervention in the area concerned make social cohesion more intensive. The intervention focusing on creative companies may reduce social inequalities and impoverishment of the society, since contrary to other industries, creative sectors comprise micro or small businesses (after family firms that employ people from local labor market).

3. State intervention prevent excessive concentration in the sector. It should be highlighted that excessive concentration prevents market competition, whereas state intervention may restore competition, e.g. by creating opportunities attracting local creative companies to the market in the case of domination of transnational corporations.

4. Financial support for research and development by the public sector is important for several reasons from the point of view of creative sectors. Primarily, it is because findings of research projects by the public sector are easily dispersed on the market. It should be emphasized that in recent several years the knowledge absorption capacity of the economy has significantly increased. Generating, using, sharing and analyzing knowledge resources is crucial for promoting economic growth and creating wealth, and the accessibility of knowledge is indispensable for developing creative companies. If we leave research and development to the invisible hand of the market, R\&D will be significantly limited due to major funding required (Budziewicz-Guźlecka 2014, p. 15).

5. To a large extent, governments are responsible for education, training, certification and licensing. Therefore, it is important to adjust the system of education to market needs to follow changes on that market and to provide citizens with employment opportunities. Thus, it is justified to intervene and 
adjust the education system in line with the requirements of the evolving more creative economy.

6. Taking care of cultural identity of the society while preserving its diversity necessitates creating opportunities to use culture for citizens, since culture is a part of the national heritage, meets higher needs that are decisive for cultural identity among members of the society. Creative sectors bring culture closer to people.

7. Production of creative goods and services provides new opportunities for women to operate on the market. Such an activity is rewarding in terms of economic benefits and personal satisfaction. Promotion of creative sectors helps including culture in the strategy to redirect the economy towards sustainable development.

8. Cultural and creative activity can be used as a means of integrating productive young people who otherwise could remain unemployed.

9. Development of creative sectors is closely linked with new communication technologies, and thus, it promotes and spreads new technologies in the society.

10. Creative sectors create a labor market. They facilitate allocation of human resources to growing sectors, increase personal income and local government revenue, as well as improve productivity, employment, and innovation.

11. Investment in creative sectors stimulate multiplication effects that lead to accelerated social and cultural regeneration, and revitalization of various areas.

12. Activity in the field of culture attracts tourists which directly (jobs, income from tickets for cultural events) and indirect (tourist spending on hotels, transportation, restaurants) influences the regional economy. Additionally, tourist attractiveness enhances the image of a city or region, which further attracts tourists and improves the perception of a given location as a place to live for citizens. Linking tourism and culture is the most vivid example of how culture influences local development and the creative sector. The creative sector stimulates the development of cultural tourism (visitor economy) and promotes spillover effects of disseminating ideas and knowledge. It is estimated that cultural tourism accounts for nearly $70 \%$ of the tourist traffic in the world.

13. Goods are produced by the creative sector locally, also when designated for export and used beyond their production area, which actually makes jobs more stable. 
14. Creative sectors support traditional production sectors. This is reflected in figures generated by those companies and their business partners. Moreover, the network of links is capable of keeping traditional sectors in their original location. For this reason, it is important to facilitate cooperation between creative companies and other market actors to establish a basis for economic growth and innovation (DCMS 2009, pp. 4-9.).

15. Activity of the creative sector involves strong social interactions. This leads to creating new skills, improves communication and dialogue between various communities and constitutes an important tool for the urban, regional and social policies. It should be highlighted that creative sectors organize urban space in cities, provide a link for local communities, and define metropolitan functions of cities. Additionally, it enhances the attractiveness of regions for citizens and investors, create images of locations, and improve quality of life and investment opportunities (both in cities and rural areas). However, benefits of public intervention in creative sectors cannot be guaranteed and may vary depending on the actual sector supported and qualities of local space.

16. Important success factor involves determining the degree and which creative sectors in a given area are considered important by the local government, as well as what type of investment is going to be the most efficient. This shows that there is no single best practice for supporting creative sectors. Any scheme should be adjusted to specific needs and take into consideration unique qualities and resources.

Investment in creative sectors influences specific areas as shown in the chart and table below.

Table 1. Influence of investment in creative sectors - analytical approach

\begin{tabular}{c|l|l|l}
\hline \multicolumn{1}{c|}{ Area } & $\begin{array}{l}\text { Influence } \\
\text { type }\end{array}$ & Details & \multicolumn{1}{c}{ Issues to be considered } \\
\hline economy & direct & $\begin{array}{l}\text { income, creation of } \\
\text { jobs, establishing } \\
\text { of businesses }\end{array}$ & $\begin{array}{l}\text { Benefits will vary in specific locations. It should } \\
\text { be checked whether influence is better in the } \\
\text { case of partnership collaboration with a region } \\
\text { or sub-region. }\end{array}$ \\
\hline Labor market & indirect & $\begin{array}{l}\text { Innovation, } \\
\text { cultural tourism } \\
\text { (visitor economy) }\end{array}$ & $\begin{array}{l}\text { Cultural tourism should be based on local } \\
\text { resources. }\end{array}$ \\
\hline
\end{tabular}




\begin{tabular}{|c|c|c|c|}
\hline regeneration & $\begin{array}{l}\text { Economic } \\
\text { and } \\
\text { material }\end{array}$ & $\begin{array}{l}\text { revitalization } \\
\text { and attracting } \\
\text { investment } \\
\text { Improvement of } \\
\text { public space }\end{array}$ & $\begin{array}{l}\text { They should be implemented in parallel with } \\
\text { other schemes focusing on improving the } \\
\text { quality of local space. }\end{array}$ \\
\hline skills & social & $\begin{array}{l}\text { Development of } \\
\text { skills }\end{array}$ & $\begin{array}{l}\text { An opportunity to involve universities and } \\
\text { schools at different levels. }\end{array}$ \\
\hline \multirow[t]{2}{*}{ space creation } & social & $\begin{array}{l}\text { Expression of } \\
\text { cultural diversity }\end{array}$ & $\begin{array}{l}\text { Creative sectors can integrate excluded } \\
\text { communities. }\end{array}$ \\
\hline & $\begin{array}{l}\text { Attractive- } \\
\text { ness of } \\
\text { locations }\end{array}$ & $\begin{array}{l}\text { Creating jobs, } \\
\text { attracting } \\
\text { companies and } \\
\text { visitors. Improved } \\
\text { quality of life for } \\
\text { residents. }\end{array}$ & $\begin{array}{l}\text { It may improve satisfaction of local space. } \\
\text { Investment attractiveness vary depending on } \\
\text { a given sector. }\end{array}$ \\
\hline
\end{tabular}

Source: Investing in creative industries: a guide for local authorities, p. 34, in: Analysis of needs..., op. cit. p. 29

The analysis of information in table 1 shows that the investment in creative sectors may influence the economy directly and indirectly.

Direct influence is expressed by creation of jobs, establishing of new businesses and growing income, whereas indirect influence on the economy concentrates on creating innovation and stimulating the development of cultural tourism that involves attracting people to a given location based on interesting and rich cultural opportunities.

The analysis of the range of influence interventions in creative sectors have on the economy requires including local differences and specific qualities. Those can be decisive regarding support provided and as well as the level of intervention. It should be highlighted, however, that in certain situations the support for creative sectors may necessitate a major intervention at the national level, whereas in other circumstances collaboration at the regional or local levels will be sufficient.

Regeneration in the context of the development of creative sectors refers, on the one hand, to material issues, investment in revitalization and improvement of public space, whereas on the other it promotes social cohesion and integration due to improved participation of citizens in culture. Since regeneration involves a systemic intervention, it is important to implement 


\section{Ekonomy}

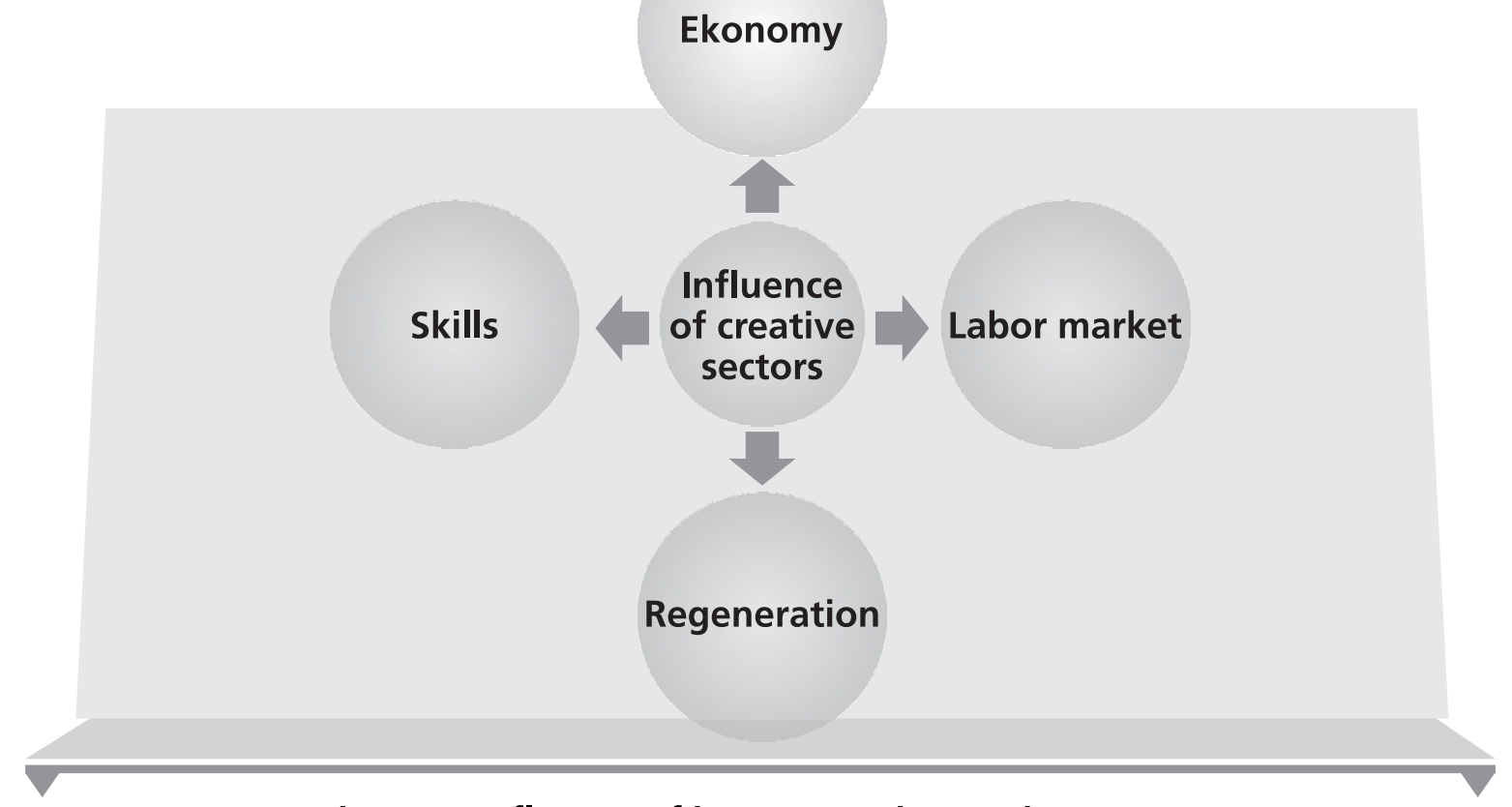

Figure 1. Influence of investment in creative sectors

Source: Analysis of needs and development of creative industries, Final Report, Ecorys, Warsaw 2009, p. 29

actions supporting creative sectors together with other schemes designed to enhance the quality of local space. New instruments should be based on local communities, their labor resources and ideas to be able to stimulate those communities.

Yet another area is the development of social skills to achieve positive influence on participants or training courses and workshops. It may also involve universities and schools at various levels to develop their offer adjusted to market needs.

Space can be developed in two dimensions: space friendly for citizens and at the same time attractive for business investment and culture tourism, as well as social space through local communities and their diversity. Another advantage of creating space of openness and tolerance is the integration of excluded communities, even when new jobs might be insufficient, and building satisfaction of local space. 


\section{Summary}

Cultural organizations and creative companies, which generate creativity, should attract more interest and support from state institutions. It should be emphasized that the local government may influence creative sectors by its authority in planning spatial development, giving concessions and licenses, adopting regulations, controlling standards of trade and the quality of healthcare system, security during mass events, and exercising its strategic and financial role in education. The support of state institutions should be based on their competences and does not require any additional financial contributions. While using relevant economic policy tools, the state at national, regional and local levels may support creative sectors by determining priorities for the socioeconomic development. It should be emphasized that creative sectors provide a wide range of benefits, including creation of interesting jobs and primarily innovation and enhancing productivity. The latter leads to improved quality of life for citizens. Additionally, creative sectors initiate new ideas, and promote exchange of opinions and views. Undoubtedly, a key area of socio-economic development is the creative sector. It should be emphasized that the level of its development and significance for economic growth of the state result from a number of conditions, such as multitude of cultures, human and intellectual capital, presence of R\&D sector, demand for products/services, and business environment (including presence of other creative companies). Nevertheless, the state policy remains the most important. State intervention in developing of the creative industry is indispensable for socio-economic development in a given area. It should be emphasized that creative industries influence the development of other sector. Thus, they further enhance the attractiveness of a given location.

\section{Summary}

\section{State intervention in the context of creative industries}

The aim of this article is to present the impact of state intervention on the development of the creative sector. The article attempts to identify the reasons why the state should lead to this kind of action. In addition, it pointed out possible areas of impact with regard to the way of influence. To achieve the objective pursued was used domestic and foreign-language specialist literature and reports of foreign institutions on the operation of creative sectors, and support were the observations of his own Polish creative sector. 
Keywords: economic policy, interventionism, creative industries.

\section{Streszczenie}

\section{Interwencjonizm państwowy w kontekście sektorów kreatywnych}

Celem artykułu jest przedstawienie wpływu interwencjonizmu państwa na rozwój sektora kreatywnego. $\mathrm{W}$ artykule podjęto próbę wskazania przyczyn, dla których państwo powinno skłaniać się do tego rodzaju działań. Ponadto wskazano na możliwe obszary wpływu z uwzględnieniem sposobu oddziaływania. Dla zrealizowania założonego celu wykorzystano krajową i obcojęzyczną literaturę fachową oraz raporty zagranicznych instytucji, dotyczące funkcjonowania sektorów kreatywnych, oraz wsparto się obserwacjami własnymi polskiego sektora kreatywnego.

\section{Słowa}

kluczowe: polityka gospodarcza, interwencjonizm, sektory kreatywne.

JEL

Classification: F1, H00, R1

\section{References}

1. Analiza potrzeb i rozwoju sektorów kreatywnych, Raport końcowy (Analysis of needs and development of creative industries, Final Report), Ecorys, Warsaw 2009, p. 29.

2. I High Level Panel on Creative Industries. Part V, p. 174.

3. Budziewicz-Guźlecka, A. (2014), Rola działalności naukowo-badawczej w rozwoju gospodarki opartej na wiedzy. Zeszyty Naukowe Uniwersytetu Szczecińskiego. Ekonomiczne Problemy Usług, (112, Vol. 1 Nowa gospodarka-spojrzenie interdyscyplinarne.) / Role of research and development in developing knowledge-based economy. Scientific Papers of Szczecin University. Economic Issues of Services, (112, Vol. 1 New economy - interdisciplinary approach.).

4. Buko J. (2009), Polityka gospodarcza, Wydawnictwo Naukowe Uniwersytetu Szczecińskiego (Economic Policy, Publishing House of Szczecin University), Szczecin.

5. Czaplewski M. (2015), Wykorzystanie polityki regionalnej w kształtowaniu rynku ustug telekomunikacyjnych, [in:] Niskoemisyjność we współczesnej polityce gospodarczej (Using regional policy in developing market of 
telecommunication services, [in:] Low emission in contemporary economic policy), scientific ed. Kazimierz Pająk, Marek Urbaniak, Sławomir Zwierzchlewski, Wydawnictwo Adam Marszałek, Torun.

6. DCMS (2004), Creative Industries Economic Estimates, Statistical Bulletin, August: 1-10, UK Government, Department of Culture, Media and Sport, London.

7. Hausner, J.,Paprocki, W. (2017), Firma-Idea oraz rozwój technologii a interwencjonizm. Centrum Myśli Strategicznych.

8. Na rzecz wsparcia kreatywności w skali lokalnej, Zeszyty Naukowe Uniwersytetu Szczecińskiego No. 793, EKONOMICZNE PROBLEMY USEUG NR 107 (for support of creativity at local scale, Scientific Papers of Szczecin University No. 793, ECONOMIC ISSUES OF SERVICES No. 107).

9. Kotylak, S. (2009), Kontrola społeczna administracji w kontekście rozwoju społeczeństwa informacyjnego. Zeszyty Naukowe Uniwersytetu Szczecińskiego. Ekonomiczne Problemy Usług, (35, Iss. 2 Rynki przesyłu i przetwarzania informacji-stan obecny and perspektywy rozwoju. Iss. 2) (Social control of administration in context of development of information society. Scientific Papers of Szczecin University. Economic Issues of Services, (35, part 2 Information transmission and processing markets current status and prospects for development. Part 2), 121-135.

10. Oakley K., Sperry B. (2008), Fine Arts and Innovation, NESTA, Working Paper.

11. Patrzałek, L. (1996), Funkcje ekonomiczne samorzadu terytorialnego w okresie transformacji systemowej w Polsce. Prace Naukowe Akademii Ekonomicznej we Wrocławiu. Seria: Monografie i Opracowania (nr 100), (714).Sztando, A. (2000), Lokalny interwencjonizm samorzadowy, czyli ksztattowanie gminnego rozwoju gospodarczego. Studia Regionalne i Lokalne, (1 (1)), 79-89.

12. Tomaszewska A.W. (2013), Przemysty kreatywne $w$ Polsce. Stan and przykłady strategii i programów (Creative industries in Poland. Status and examples of strategies and programs).

13. UNCTAD (2004), UN Conference on Trade and Development, Proceedings of the Workshop. 